33. Scharpf, F. W. (1991). Crisis and choice in European social democracy. Cornell University Press, 303 p.

34. Schwartz, H. (2001). Round up the usual suspects! Globalisation, domestic politics, and welfare state change. P Pierson (Ed.), New Politics of the Welfare State. New York: Oxford University Press, 303 p.

35. Wade, R. (1996). Globalisation and its limits: Reports of the death of the national economy are greatly exaggerated. S. Berger, R. Dore (Eds.), National Diversity and Global Capitalism. Ithaca: Cornell University Press, 387 p.

Стаття надійшла до редколегії 24.09.2019 p.

УДК 659.3.32

Наталія Лютко,

кандидат політичних наук,

доцент кафедри філософії і політології,

Хмельницький національний університет, Україна,

https://orcid.org/0000-0002-8792-5035

liutkonv@ukr.net

\title{
ДЕЯКІ МІРКУВАННЯ ЩОДО ВИКОРИСТАННЯ СИМВОЛІВ У ПОЛІТИЧНІЙ РЕКЛАМІ
}

У статті розглянуто трактування поняття «символ» та його комунікативний потенціал. Зазначено щцо символи $\epsilon$ основним засобом репрезентації політичних акторів і подій, комунікаиії між владою й суспільством, ефективним інструментом побудови політичної реальності, а також тим, щзо в політичній рекламі використовуються для віртуальної видозміни політичної та соціальної дійсності, передачі якоїсь думки щчодо політичних процесів $i$ формування потрібних емоцій у громадян. Відзначено, щзо комунікативне призначення політичної реклами полягає в тому, щьо вона покликана встановити контакт між носіями влади або претендентами на місия у владних структурах, $i$ громадянами, акумулювати в рекламному повідомленні основну концепцію виборчої кампанії. Установлено щзо політична реклама стає своєрідним провідником ідей, ретранслятором образів, символів, міфів, які живуть і функціонують у масовій свідомості суспільства. Політична реклама також перетворюється в технологію симуляиії, виробництва віртуальної реальності (i віртуальних іміджів), посилюючи театралізацію політичного життя й відволікаючи вибориів від справжніх проблем та потреб. Успішне виконання комунікативних завдань політичної реклами неможливе без детального дослідження політичного простору (законодавчої, політичної, демографічної й економічної ситуацї, системи влади, розстановки сил на політичній арені, в економічній сфері та ін.). Обгрунтовано, щу задля досягнення максимальної ефективності комунікації політичної реклами

(C) Лютко H., 2019 
особливу увагу потрібно приділяти вивченню громадської думки, потреб, мотивацій $i$ переваг вибориів, визначенню иілььових аудиторій.

Ключові слова: символ; політичні символи; політична комунікачія; політична реклама.

\section{1. ВСТУП}

Постановка наукової проблеми. Сучасна політична реальність набуває не просто символічного характеру, символічна дійсність перетворює сферу політики на сферу виробництва символів. Ці тенденції дедалі більше зумовлюють пошуки нових теоретико-методологічних підходів до визначення впливу символів на процеси конструювання та відтворення політичного життя. У цьому сенсі потрібно звернутися до настанови, яку пропонує В. Мудраков, ураховуючи іï філософський складник: «Методологічні топоси теоретизування над політичним буттям грунтуються на філософії як такій, оскільки саме вона, на відміну від спеціальних галузей політичного знання, має потенціал до самовивершення як загальної теорії політичної онтології. Ба більше, вона відіграє роль теорії політичного пізнання. Особливістю й значущістю філософських впливів на методологію осмислення специфікації пізнання політичних явищ $\epsilon$ взаємозв'язок політичної дійсності із рецептивністю (iї якістю) щодо політичної дійсності. (Мудраков В. 2017, с. 159). Символи $\epsilon$ основним засобом репрезентації політичних акторів і подій, комунікації між владою й суспільством, а також ефективним інструментом побудови політичної реальності. Під час створення політичної реклами потрібно врахувати іiі функціональну особливість-здатність до форматування й поширення політичних символів, що зумовлює актуальність дослідження.

Аналіз досліджень і публікацій. Серед учених, які бодай дотично мали стосунок до смислових засновків проблеми співіснування символу й реклами, можемо виокремити У. Еко, Е. Кассірера, Ж. Бодріяра, О. Феофанова, Л. Підгірну, А. Шюца, У. Джеймса, Дж. Міда, Г. Келлі, М. Едельмана, П. Бергера та Т. Лукмана. Потрібно відзначити також праці таких вітчизняних науковців, як В. Бебик, М. Головатий, В. Горбатенко, С. Демченко, В. Зірка, Л. Кочубей, Л. Павлюк, Г. Почепцов, Ю. Шайгородський, Ю. Щербакова.

Метою цієї праці $є$ розгляд особливостей використання символів у політичній рекламі.

\section{2. РЕЗУЛЬТАТИ ДОСЛІДЖЕННЯ}

Феномен символу сягає своїм корінням у ті далекі часи формування людської культури, коли постає необхідність утілити абстрактний зміст у наочному вигляді, під час спілкування людини 3 вищими, потойбічними силами, прихованими від безпосередніх контактів. Міфологічна, релігійна, містична символіка сформувалась у величезний пласт духовної культури. Один 3 авторитетів теорії символізму Ернст Кассірер так писав про всепроникаючу присутність символів у мистецтві й повсякденних політичних та економічних 
процесах: «символізм обволікає людство ніжною і прозорою, але міцною вуаллю» (Кассирер, 1995, с. 200). Таке розуміння стане для нас засадничим.

Політика, як і інші сфери суспільного життя, породжує свій символічний світ. Специфічною особливістю політичної символіки є їі знаковість. Це знак, який виконує комунікативну функцію між громадянином і владою. Це умовний зразок найважливіших політичних ідеалів, засіб їхньої пропаганди й утвердження.

Символічні атрибути влади містять усе, що пов'язано з цією політичною системою, iii історією, дійсністю й майбутнім. Особливо багато символіки використовують армія, державні служби, суди, прокуратура тощо. Символ не може бути повністю зрозумілим, він розкривається суспільству в історії й кожній людині в іiі житті. Чим більш насичене політичне життя, тим глибше проникнення в зміст символів. Символізм потребує культури та активного ставлення до символічної реальності. (Лісовська, 2010).

За допомогою символів створюються основні соціальні позиціювання. Символічний означальний ресурс розмежовує «своє» і «вороже», бажане та небажане, вони і ми. Символічна мова схиляє до однозначного вибору «за» чи «проти», намагаючись привабити позитивом і відлякати вказівкою на негативи соціальної дійсності, підкреслені за допомогою експресивних означників. (Павлюк, 2006). Головною особливістю символів є нескінченна кількість внутрішніх значень, що реалізуються в зовнішніх проявах. Це сприяє тому, що символ передає інформацію миттєво, минаючи всі перешкоди для іiї критичного осмислення реципієнтами. Виходячи з цього, зазначимо, що політичні символи - потужний ретранслятор у дискурсивних практиках взаємодії політичних акторів, зокрема представників влади, громадян і суспільства. Політичні символи допомагають регулювати відносини індивіда та політичної системи.

Фахівець із теорії політичної комунікації М. Едельман розробляє теорію символів у політичній комунікації, яка бере до уваги міру конотативного багатства знака i його здатність виконувати переважно номінативну, референтну чи експресивну, емоційну функцію. Відповідно, М. Едельман розрізняє референтні символи, за якими стоїть реальний фізичний об'єкт, конкретна особа й конденсаційні символи, до функціональних особливостей яких належить передусім генерування бажаних психологічних станів. При сприйманні конденсаційних символів людина абстрагується від реальних об'єктів, які стоять за ними, і занурюється в конотативну ауру знака.

Конденсовані символи викликають емоції, пов'язані із ситуацією. В одну символічну подію, знак або вчинок вони спресовують патріотичну гордість, хвилювання, спогади про минулу славу чи приниження, обіцянки майбутньої величі - окремі $з$ цих емоцій чи всі їх разом (Edelman, 1964, p. 6).

Саме комунікативний потенціал символу пов'язаний із такими його властивостями, як ретроактивність щодо культурного досвіду індивіда (як окремого індивіда та як масової людини водночас) і проактивність щодо тексту медіа-повідомлення, що сприймається. Завдяки символічній ретроактивності індивід виявляє себе в певній успадкованій культурній традиції. Символічний 
складник значно полегшує процедуру декодування медіа-повідомлень, адже актуалізує спільне смислове поле. Отже, застосування символів як смислових засобів певною мірою нівелює проблему множинності інтерпретацій. У такому сенсі символ виступає важливим чинником керованості й контрольованості сприйняття повідомлень. Власне, у цьому й виявляється така його властивість, як проактивність, а отже, i технологічність символу як комунікаційного інструмента (Ярошенко, Присяжненко, 2014).

Зі свого боку, Г. Почепцов, С. Чукут основну увагу приділяють практичному напряму дослідження політичної символіки, аналізують якості політичних символів, визначають вимоги, яким вони мають відповідати. У праці «Інформаційна політика» дослідники стверджують: ми живемо у світі, що складається зі сфер: реальної, інформаційної й символічної. Між цими трьома світами існують певні бар'єри. У світі реальному відбуваються тисячі подій, однак лише поодинокі переходять у світ інформаційний. Зі свого боку, у світі інформаційному відбуваються сотні подій, проте лише невелика частина переходить у світ символічний (Почепцов, Чукут, 2008, с. 237).

У системі політичного ринку символи використовують для створення бренду, побудови та репрезентації іміджу, для спрощення комунікативного процесу між політичними акторами й аудиторією як бренд, завдяки якому впізнають ту чи іншу політичну силу, що сприяє іï просуванню на політичному ринку. У політичному маркетингу символи поширюються як логотипи, знаки, емблеми, котрі вказують на належність до певного суб'єкта, позиціонують його й дають змогу виділити його з групи аналогічних суб'єктів. Відбувається проекція характеристик i якостей суб'єкта на символ. У випадку, коли обирається символ, який уже володіє певними характеристиками, то ці характеристики екстраполюються на суб'єкт. Символ починає заміщувати політичного актора, в відтак відбувається заміна реального на віртуальне. (Символічна складова реклами у політичному маркетингу) (Білівітіна, 2011, с. 101).

Отже, у наш час символи в політичній рекламі використовують для віртуального спрощення політичної та соціальної дійсності, передачі якоїсь думки щодо політичних процесів і формування потрібних емоцій у громадян. Важливим чинником у процесі рекламної комунікації можуть бути мова, релігія, освіта, національна та культурна належність, ерудиція тощо. Тому суб'єктам політичного маркетингу потрібно звертати особливу увагу на знаки й символи, які вони застосовують, щоби інформація, котру вони передають, була сприйнята реципієнтом відповідно до того сенсу, який бажає передати комунікатор.

Успішне виконання комунікативних завдань політичної реклами неможливо без детального дослідження політичного простору (законодавчої, політичної, демографічної та економічної ситуації, системи влади, розстановки сил на політичній арені, в економічній сфері й т. ін.). Стан цього простору та ситуативні зміни багато в чому визначають спрямованість дій виборців. Щоб досягти максимальної ефективності комунікації політичної реклами, особливу 
увагу потрібно приділяти вивченню громадської думки, потреб, мотивацій i переваг виборців, визначення цільових аудиторій. Як посередник між лідером i виборцями в політичній комунікації виступає імідж політика. Він постійно відтворюється самим суб'єктом та засобами комунікації. Специфіка іміджевої комунікації полягає ще й у тому, що повідомлення створюються з урахуванням очікуваної реакції населення. Використання символу в політичній рекламі зумовлено полем емоційної аргументації. Необхідністю в стислий час (наприклад час рекламного ролика або час, витрачений на «зчитування» інформації з вуличних рекламних носіїв) делегувати ідеї причетності певної партії до можливості розв'язання різноманітних соціально значущих проблем населення, вплинути на можливість ідентифікації особистості 3 певною політичною групою й забезпечити швидке розпізнавання інформації конкретної партії серед інформаційного «шуму» передвиборної агітації. (Витюк, 2006)

В акті символізації концентрується цінна грань рекламного креативу: це найбільш виразний спосіб кристалізації опорної ідеї повідомлення. Саме символ як компонент рекламного тексту здатний «зачепити» увагу реципієнта, викликати в нього інтерес, спонукати до дії на отриману пропозицію.

Політична реклама все частіше працює 3 образами, товарами, популярністю й продажами, ніж із цінностями та переконаннями. Комунікативне призначення політичної реклами полягає в тому, що вона покликана встановити контакт між носіями влади або претендентами на місця у владних структурах і громадянами, акумулювати в рекламному повідомленні основну концепцію виборчої кампанії. Політична реклама, відображаючи суть політичної платформи певних політичних сил, направляє виборців на їх підтримку, формує й упроваджує в масову свідомість певне уявлення про характер цих політичних сил, створює бажану психологічну установку на голосування. Вона здійснює певним чином спрямований адресний зв'язок між ними, використовуючи гранично доступну для сприйняття та адекватну основній масі населення знакову систему. Тому політична реклама стає своєрідним провідником ідей, ретранслятором образів, символів, міфів, які живуть і функціонують у масовій свідомості суспільства. Політична реклама також знайомить електорат із різними кандидатами, їхніми поглядами, політичними акціями, їх перевагами перед конкурентами.

Одночасно в рекламні повідомлення можуть свідомо закладатися громадські чи групові стереотипи й ілюзії, щоб відволікати виборців від справжніх громадських проблем і справжніх цілей політичних сил у їх боротьбі за владу.

Змінюється сама культура: символічні форми починають домінувати над смисловими. Образ створює порожнечу й саме в цьому його натякаюча сила. (Бодрійяр, 2001). Фактично реклама прагне орієнтувати людей на копіювання, імітацію власної дії. Цей факт відзначає й Гі Дебор, коли пише, що «все життя суспільств, де панують сучасні умови виробництва, проявляється як загальне накопичення спектаклів» (Дебор, 1999, с. 23). Але, на його думку, процеси театралізації всього суспільного життя зайшли так далеко, що потрібно говорити не просто про стирання кордонів між життям і спектаклем, але й про 
докорінні фальсифікації та підміни цих понять. Отже, у суспільстві, на думку Гі Дебора, проходить фактична інверсія реальності й спектаклю: «реальність виникає в спектаклі, а спектакль є дійсністю» (Дебор, 1999, с. 25).

Продовжуючи цю традицію, Ж.Бодрійяр, стверджує, що глядачі стають акторами, вони замінюють собою виконавців головних ролей і під наглядом ЗМІ здійснюють постановку власної вистави (Бодрийяр, 2001). У повсякденному житті людина постійно приймає образи сценічних персонажів, сприймає чужі для неї моделі поведінки, усе більше віддаляючись від самої себе й наближаючись до примарного образу віртуального героя. Використовуючи ідеї Ж. Бодрійяра, можемо стверджувати, що симуляція пронизує всі сфери сучасних суспільних відносин, і політичні теж. Із цього погляду політична реклама перетворюється в технологію симуляції, технологію виробництва віртуальної реальності (і віртуальних іміджів) за короткий та водночас на короткий проміжок часу (період передвиборної кампаніï). Політична реклама покликана конструювати віртуальний простір, у якому функціонуватимуть симулякри (кандидати, партії, програми, ідеї й т. ін.), тобто повинна здійснюватися «заміна реального знаками нереального». Існує різниця між кандидатом на початку виборів, коли приймається рішення про участь у передвиборній гонці, та на іiі фінальному етапі. Виборча кампанія являє собою процес, протягом якого відбувається поділ образу кандидата на «кандидата - реального» й «кандидата симулякра». За Ж. Бодрійяром, щоб стати симулякром, образ повинен пройти низку послідовних стадій: він є відображенням базової реальності, він маскує й спотворює базову реальність, він маскує відсутність базової реальності, він не має ніякого стосунку до будь-якої реальності, він $\epsilon$ своїм власним чистим симулякром. Під дією симулякрів, політичний вибір громадянина, його волевиявлення - досить складно побудований і тонкий механізм, робота якого залежить від прихованого впливу різних закономірних та випадкових факторів. До них можна віднести ідеологічні установки виборця, його інтерес до політики, соціальний статус, характер трудової діяльності й матеріальний рівень, стать, вік, оточення. Отже, модель поведінки виборця залежатиме від його соціальних характеристик і біографії, особистісних якостей, культурно-освітнього рівня, умов життя, віку, впливу середовища, у якому він обертається. Вона також включатиме і його сформовані політичні позиції, принципи загальнолюдської й політичної моралі, думки щодо тих чи інших поточних політичних проблем, ставлення до «команди» кандидата, із якої він виходить на вибори, звичок голосування й т. ін.

Серед об'єктивних чинників, що визначають політичні преференції тих чи інших виборців, - їхні етнічні та релігійні особливості, і пов'язані з ними політичні традиції, а також місцеве й політичне оточення виборця. В умовах сучасного українського суспільства етнічний та регіональний чинники посилили його тенденції до диференціації. Тому, плануючи рекламну кампанію, треба враховувати всі стереотипи, особливості поведінки, символи, міфи й традиції, які визначають самосвідомість етносу як окремої, відмінної, а інколи такої, яка протистоїть іншим, спільності. Етнічний фактор впливає на 
поведінку виборця в поєднанні із соціально-демографічними та економічними обставинами, релігійними традиціями.

Як самостійний суб'єктивний фактор політичного вибору можемо визначити й інтерес до політики. Немає необхідності доводити, що електоральна поведінка безпосередньо залежить від того, наскільки повно виборець уключений у політичне життя суспільства. Інтерес до політики визначає низку інших ознак, таких, наприклад, як рівень політичних знань людини, його знання про стан справ у політичному житті суспільства, ступінь довіри виборця до тих чи інших політичних структур і деякі інші, які зумовлюють саме поняття «політична культура». Отже, у низці важливих i довготривалих чинників, що впливають на політичний вибір, одне з головних місць займають ідеологічні установки й політична культура. Інтерпретацію будь-політичної події або проблеми, оцінку будь-якого політичного документа чи політичного лідера виборець співвідносить, насамперед, із тими політичними цінностями, які притаманні йому самому. Політичні вподобання виборців сучасного українського суспільства досить нестійкі, на відміну від тих країн, де консолідувалися демократичні системи, де спостерігається більшменш постійна прихильність виборців до окремих партій. Як і в будь-якому іншому суспільстві, політичні пріоритети сучасного українського виборця визначаються, передусім, типом політичної культури.

\section{3. ВИСНОВКИ ТА ПЕРСПЕКТИВИ ПОДІЛЬШИХ ДОСЛІДЖЕНЬ}

У сучасній політиці символи політичної реклами перестали бути символами й стали знаками: вони більше не відсилають до реальності, до емоцій, надій та очікувань, - вони стають подобою знаків арифметичних дій або військових відзнак: вони не несуть ніякого емоційного або естетичного навантаження, а лише повідомляють інформацію «зараз перед вами виступає кандидат такий-то». На цьому символічному тлі, все більше нагадує інформаційний шум, яскраво й чітко виділяються лише символи державності, а також символи радикальних політичних рухів. Політична реклама являє собою диференційовану, багатоцільову, багатофункціональну форму політичної комунікації в умовах здійснення політичного вибору. Вона передбачає в лаконічній, оригінальній формі, яка легко запам'ятовується, адресний вплив на численні електоральні групи. Політична реклама стає своєрідним провідником ідей, ретранслятором образів, символів, міфів, які живуть і функціонують у масовій свідомості суспільства. Політична реклама також перетворюється в технологію симуляції, виробництва віртуальної реальності (i віртуальних іміджів також), посилюючи театралізацію політичного життя й відволікаючи виборців від справжніх громадських проблем і потреб виборців, що вимагає подальших досліджень.

\section{СПИСОК ВИКОРИСТАНИХ ДЖЕРЕЛ}

1. Білівітіна, А. (2011). Символічна складова реклами у політичному маркетингу. Політичний маркетинг, 3, 98-106. 
2. Бодрийяр, Ж. (2001). Система вещей. Москва: РУДОМИНО. URL: http://yanko.lib.ru/ books/philosoph/baudrillard-le-systeme-des-objets.htm

3. Витюк, С. С. (2006) Особенности символа в политической коммуникации (на примере предвыборных рекламных кампаний в Украине. Майские чтения. URL:http://maiskoechtivo.pstu.ru/2006/4/3.htm

4. Дебор, Г. (1999). Общество спектакля. Москва: Логос.

5. Кассирер, Э. (1995). Философия символических форм. Т. 1. Введение и постановка проблемы. Культурология. ХХ век. Антология. Москва: Юрист, с. 163-212.

6. Лісовська, М. (2010). Проблема політичної символіки у вітчизняній та зарубіжній політології. Віче. 10, 15-17. URL: http://nbuv.gov.ua/UJRN/viche_2010_10_7

7. Мудраков, В. (2017). Філософсько-методологічне осмислення політичного пізнання. Гуманітарно-наукове знання: комунікативні засади. Матеріали Міжнародної наукової конферениії, 6-7 жовт. 2017 р., 159-162.

8. Павлюк, Л. (2006). Символ та ідентифікація в політичному дискурсі мас-медіа. Журналістика:науковий збірник, Вип. 5, C. 48-57. URL: http://old.journ.lnu.edu.ua/ publications/visnyk26/Statti_Pavljuk.htm

9. Почепцов, Г., Чукут, С. (2008). Інформаційна політика. Київ: Знання.

10. Ярошенко, В., Присяжненко, О. (2014). Символічна політика та символи в інформаційно-комунікативному просторі: аспекти впливу. Наукові праці Чорноморського державного університету імені Петра Могили комплексу «Києво-Могилянська академія. Політологія», Т. 248, Вип. 236, С. 28-33. URL: http://nbuv.gov.ua/UJRN/Npchdupol_ 2014_248_236_6

11. Edelman, M. (1964). The Symbolic uses of Politics. Urbana: Un-ty of Illinois Press.

\section{SOME CONSIDERATIONS CONCERNING THE USE OF SYMBOLS IN POLITICAL ADVERTISING}

The article deals with the interpretation of the concept of "symbol" and its communicative potential. It is stated that symbols are the main means of representing political actors and events, communication between the authorities and society, as well as an effective tool for building political reality, as well as that in political advertising they are used for virtual modification of political and social reality, transmitting some opinion on political processes and forming necessary emotions in citizens. It is determined that the communicative purpose of political advertising is that it aims to make contact between the media or candidates for positions in power structures and citizens, to accumulate in the advertising message the basic concept of the election campaign. It is established that political advertising becomes a kind of conduit of ideas, a repeater of images, symbols, myths that live and function in the mass consciousness of society. Political advertising is also turning into a technology of simulation, production of virtual reality (and virtual images), enhancing the theatricalization of political life and distracting voters from real problems and needs. Successful solution of the communicative problems of political advertising is impossible without a detailed study of political space (legislative, political, demographic and economic situation, the system of power, the deployment of forces in the political arena, in the economic sphere, etc.). It is substantiated that in order to maximize the effectiveness of political advertising communication, special attention should be paid to the study of public opinion, needs, motivations and preferences of voters, determination of target audiences.

Key words: symbol; political symbols; political communication; political advertising.

\section{REFERENCES}

1. Bilivitina, A. (2011). Symbolic component of advertising in political marketing. Politychnyi marketynh. 3, 98-106 (in Ukrainian). 
2. Bodrijjar, Zh. (2001). System of things. Moskva: RUDOMINO (in Russian).

3. Vitjuk, S. S. (2006) Character features in political communication (on the example of election campaigns in Ukraine. Majskie chtenija. URL:http://maiskoechtivo.pstu.ru/2006/4/3.htm (in Russian).

4. Debor, G. (1999). Performance society. Moskva: Logos (in Russian).

5. Kassirer, Je. (1995). The philosophy of symbolic forms. Vol. 1. Introduction and statement of the problem. Kul'turologija. XX vek. Antologija. Moskva: Jurist, P. 163-212 (in Russian).

6. Lisovska, M. (2010). The problem of political symbolism in domestic and foreign political science. Viche. 10, 15-17. URL: http://nbuv.gov.ua/UJRN/viche_2010_10_7 (in Ukrainian).

7. Mudrakov, V. (2017). Philosophical and methodological understanding of political knowledge. Humanitarno-naukove znannia: komunikatyvni zasady: Materialy Mizhnarodnoi naukovoi konferentsii (6-7 zhovtnia 2017 r.), 159-162 (in Ukrainian).

8. Pavliuk, L. (2006). Symbolism and identification in the political discourse of the media. Zhurnalistyka: naukovyi zbirnyk, Vyp. 5, P. 48-57. URL: http://old.journ.lnu.edu.ua/ publications/visnyk26/Statti_Pavljuk.htm (in Ukrainian)

9. Pocheptsov, H., Chukut, S. (2008). Information policy. Kyiv: Znannia (in Ukrainian).

10. Iaroshenko, V., Prysiazhnenko, O. (2014). Symbolic politics and symbols in the information and communication space: aspects of influence. Naukovi pratsi Chornomorskoho derzhavnoho universytetu imeni Petra Mohyly kompleksu «Kyievo-Mohylianska akademiia. Politolohiia», T. 248, Vyp. 236. P. 28-33. URL: http://nbuv.gov.ua/UJRN/Npchdupol_ 2014_248_236_6 (in Ukrainian).

11. Edelman, M. (1964). The Symbolic Uses of Politics. Urbana: Un-ty of Illinois Press (in English).

Матеріал надійшов до редакції 12.08.2019 р.

\section{УДК 811}

\section{Віра Максимець,}

кандидат політичних наук, доцент кафедри міжнародної інформації, Національний університет «Львівська політехніка», 79000, Україна, Львів, пл. Св. Юра, 3, каб. 126

e-mail: maksymetsvira@ukr.net

https://orcid.org/0000-0002-9003-7055

\section{Тетяна Свірідова,}

студентка 2 курсу магістратури спеціалізації «Міжнародна інформація», Національний університет «Львівська політехніка», Львів, Україна e-mail: tetiana.sviridova.mmv.2018@1pnu.ua

\section{ТРАНСФОРМАЦІЯ ПОЛІТИЧНИХ ВИБОРЧИХ КАМПАНІЙ В ЕРУ ВІG DАТА ТЕХНОЛОГІЙ}

У статті представлено практичні основи необхідності використання новітніх технологій для проведення політичних кампаній. Висвітлено вплив використання Віg Data технологій на прочес виборчих кампаній. Установлено, щзо технологї, які 